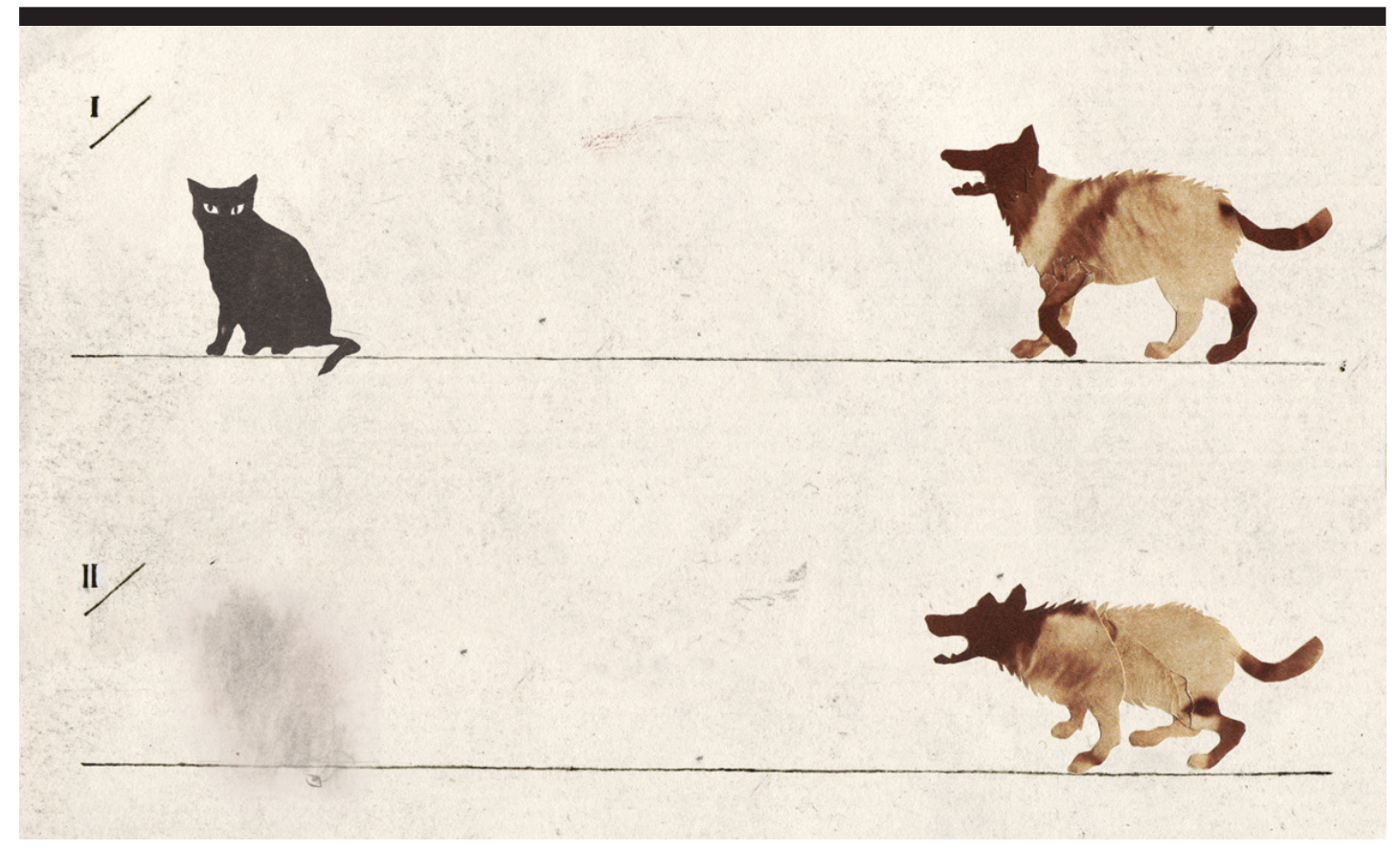

Ilustracja: Natalia Kulka

\title{
Żydzi w dyskursie Kościoła katolickiego
}

\author{
Marzena Makuchowska
}

\begin{abstract}
Abstrakt: Artykuł opisuje ważne zmiany w dyskursie Kościoła katolickiego w odniesieniu do wyznawców judaizmu, które pojawiły się po Soborze Watykańskim II. Jedną z nich jest różnica pomiędzy stanem tekstów w dwóch różnych momentach: przed i po soborze. Dlatego pierwszą część artykułu autorka poświęca charakterystyce przedsoborowego (i w większości przedwojennego) dyskursu na temat Żydów, a część drugą głównym kierunkom zmian spowodowanym realizacją postulatów soboru. Część trzecia pokazuje objawy kontynuacji starych, głęboko zakorzenionych schematów. Analiza częściowo odnosi się do ogólnych tekstów Kościoła, a częściowo do tekstów Kościoła publikowanych w Polsce.
\end{abstract}

Polski przedsoborowy dyskurs o Żydach był wyjątkowo negatywny. Liturgia katolicka przedstawiała Żydów jako tych, którzy torturowali i zabili Jezusa (mit bogobójcy). W kazaniach, listach duszpasterskich i katolickiej prasie Żydów pokazywano jako wrogów nie tylko chrześcijan, lecz szczególnie Polaków, ponieważ Kościót w Polsce zaangażował się w kreowanie narodowo i religijnie homogenicznego kraju pod sloganem „Polska dla Polaków”. Reprodukowano wszystkie tradycyjne mity (Żydzi jako szkodnicy, spiskowcy, rozpustnicy itd). Używano wiele środków lingwistycznych, by zdegradować Żydów, np. zdrobnienia, animalizację (czyli mówienie o Żydach jako o zwierzętach) czy tak zwany kakofemizm (czyli używanie słów o pejoratywnym znaczeniu), aby sprowokować uczucie moralnego i fizycznego obrzydzenia.

Po Vaticanum // treści reprodukujące przedstawienie Żydów jako bogobójców zostały usunięte z liturgii. Pozytywny obraz Żydów i judaizmu był konsekwentnie kreowany w naukach papieży Jana Pawła II i Benedykta XVI. Lingwistyczne środki podkreślają wspólnotę chrześcijan i Żydów (więź, bliskość, bracia, braterstwo, razem itd.). Papieże zobowiązują katolików do szanowania Żydów i pamięci Holokaustu, bezpośrednio zakazują jakichkolwiek przejawów antysemityzmu.

W Polsce po 1989 roku antyżydowskie tendencje znów ożyły, szczególnie w kręgach tak zwanych radiomaryjnych. Ponownie Żydzi oskarżani są o powodowanie szkód Polsce i Polakom, a język tych twierdzeń bardzo przypomina dyskursy przedsoborowe.

Wyrażenia kluczowe: dyskurs Kościoła katolickiego; Sobór Watykański II; Żydzi; znaczenia językowe; dyskredytowanie; stereotypy 
Mija pół wieku od II Soboru Watykańskiego (1962-1965), który zadekretował szereg tak gruntownych zmian, iż często określa się go „przełomem kopernikańskim” w Kościele katolickim. Przede wszystkim chodzi o proklamację radykalnej zmiany stosunku katolików do niekatolików, czyli do ludzi innych wyznań chrześcijańskich, innych religii oraz niewierzących. Charakter nowej epoki wyznaczyć miał pozytywny, nacechowany szacunkiem i miłością stosunek do każdego człowieka, bez względu na jego wiarę czy światopogląd. Zmianę postawy Kościoła wobec innych religii ogłoszono w przyjętej pod koniec 1965 roku Deklaracji o stosunku Kościoła do religii niechrześcijańskich „Nostra aetate". Sobór odnosi się w niej kolejno do hinduizmu i buddyzmu, szerzej do islamu i stosunkowo najobszerniej (cały dokument jest niewielkim tekstem) do judaizmu ze względu - jak pisze historyk Ralph Wiltgen - na „szczególne znaczenie narodu żydowskiego w planie Zbawienia” (Wiltgen, 2001, s. 222), ale także z poczucia szczególnego obowiązku wobec żydów ${ }^{1}$, którzy w łonie kultury chrześcijańskiej zaznali ogromu cierpień, z tragedią Holokaustu jako ich kulminacją².

W kolejnych latach powołano wiele instytucji do kształtowania nowych relacji z żydami, wydano szereg istotnych dokumentów; naukę soborową rozwijał papież Jan Paweł II, który też dokonał względem żydów (jak i innych wyznań oraz religii) kilka historycznych gestów (wejście do synagogi, przeprosiny w 2000 roku i in.). Przyjęto określoną politykę językową, która z jednej strony miała polegać na usuwaniu antysemickich treści z nauczania Kościoła, a z drugiej - służyć stwarzaniu dobrych stosunków i autentycznej więzi między żydami a chrześcijanami, niezależnie od postępów w zbliżeniu na płaszczyźnie teologicznej.

Niniejszy artykuł ${ }^{3}$ jest próbą przedstawienia najważniejszych przemian, jakie zaszły w dyskursie Kościoła katolickiego w związku ze zmianą jego stanowiska wobec wyznawców judaizmu. Zmiana to różnica między postacią tekstów w dwóch różnych okresach, dlatego pierwsza część artykułu poświęcona jest charakterystyce przedsoborowego (i w większości przedwojennego) dyskursu o Żydach, a druga przedstawia główne kierunki przemian wywołanych realizacją soborowych postulatów. Trzecia część natomiast pokazuje przejawy ciągłości negatywnej tradycji czy też jej siły bezwładności, która hamuje proces odrzucenia starych, silnie zakorzenionych schematów. Jak się

1 Zgodnie z zasadami polskiej ortografii wyraz żyd pisany małą literą oznacza wyznawcę judaizmu, natomiast użycie wielkiej litery: Żyd oznacza członka narodu (tzw. etnonim). Ponieważ jednak najczęściej zakresy obu słów się pokrywają, jest to zasada trudna do konsekwentnego stosowania. Małej litery używam więc tam, gdzie kontekst wyraźniej podkreśla religię, w pozostałych wypadkach natomiast piszę: Żyd.

Nota bene można się zastanawiać, czy powszechne dziś w literaturze naukowej pisanie Żyd za każdym razem jest motywowane zamiarem nadania temu słowu znaczenia etnonimicznego, czy też raczej chęcią uniknięcia deprecjonującego efektu minuskuły. Jednak podkreślanie odrębności narodowej Żydów było (i bywa nadal) jedną z form ich dyskryminacji, wykluczenia z własnej (np. niemieckiej czy polskiej) wspólnoty etnicznej; wielka litera niekoniecznie więc musi wyrażać pozytywny sens.

2 Według relacji R. Wiltgena konieczność sporządzenia dokumentu mówiącego o judaizmie wyraził papież Jan XXIII jeszcze w fazie przygotowań do soboru. Ostateczny kształt Deklaracji „Nostra aetate”, która nie odnosi się tylko do judaizmu, ale także do innych religii niechrześcijańskich, wyniknął ze specyficznej sytuacji politycznej, jaka miała miejsce w czasie, gdy obradował sobór (zob. Wiltgen, 2001, ss. 212-223).

3 Artykuł porusza kwestie, które znalazły szersze rozwinięcie w mojej książce pt. Od wrogów do braci. Posoborowe zmiany w dyskursie Kościoła katolickiego (Makuchowska, 2011). 
okazuje, nie wszyscy z entuzjazmem przyjmują soborowe idee zbliżenia katolików do innych religii, lub - akceptując same idee - nie aprobują form i efektów prowadzonej w tej dziedzinie praktyki.

\section{Dyskurs przedsoborowy}

\section{1. Żydzi w tekstach liturgicznych}

O trudnych relacjach chrześcijańsko-żydowskich zadecydowały koncepcje teologiczne ukazujące Żydów jako odpowiedzialnych za ukrzyżowanie i śmierć Jezusa oraz usuwające ich w cień jako „stary” lud Boży, odrzucony przez Boga i zastąpiony „nowym”, którym jest Kościół (por. Pałka, 2006, s. 363). Udział Żydów w martyrologii Chrystusa stanowił element przedstawień o treści pasyjnej, które mają w kulturze europejskiej wyjątkowo długą i bogatą historię (por. Wojtyska \& Kopeć, 1981; Korolko, 2001; Woźniak, 2007). Kult cierpiącego Syna Bożego upowszechniały w średniowieczu różnorakie szkoły i kierunki ascetyczno-mistyczne, inspirowane zwłaszcza przez teologów zakonów żebraczych, głównie franciszkanów. Wydarzenia Wielkiego Tygodnia, będące kulminacją liturgii chrześcijańskiej, rozważano, opiewano i obrazowano w najróżniejszych formach liturgicznych i paraliturgicznych, jak nabożeństwa, dramaty, misteria, narracje oraz liczne pieśni. W baroku pobożność pokutno-pasyjna jeszcze bardziej przybrała na sile, zyskując też wówczas swoiste, lokalne oblicze, wyrażające się w rozbudowanych obrazach cierpień Jezusa i dolorystycznym stylu obrazowania. Z tego okresu pochodzi żywotna do dziś pieśń Ludu, mój ludu, cóżem ci uczynił, a jeszcze w czasach przedrozbiorowych ukształtował się zasadniczy kanon polskich pieśni pasyjnych (Korolko, 2001, s. 55 n.).

Teksty o tej tematyce i funkcji łączy zespół powtarzalnych motywów, zaczerpniętych przede wszystkim z Biblii, ale nie tylko. Obraz Żydów ma trwały kontur, rysowany za pomocą tych samych, obiegowych środków językowo-stylistycznych i tekstowych. Żydzi występują jako ci, którzy w Ogrodzie Oliwnym pojmali Chrystusa, wodzili Go przed Annasza, Kajfasza i Heroda, wymusili na Piłacie niesprawiedliwy wyrok, zadawali Chrystusowi męki fizyczne i psychiczne, przyprawili o haniebną śmierć, a potem jeszcze „szarpali imię Jego, gdy ciała już nie mogli” (Skarbiec modlitw i pieśni, 1947, s. 262). Występowanie wciąż w tych samych rolach rozpisanych w powtarzalnym schemacie fabularnym wiązało się z utrwalaniem silnie negatywnego wizerunku Żydów, charakteryzowanych ustalonym zestawem cech, które przypisywano im niejako automatycznie. Poniższa analiza pokazuje, za pomocą jakich środków językowo-tekstowych taki właśnie obraz Żydów budowały oficjalne teksty wielkopostne, użytkowane w katolickich kościołach jeszcze w przedsoborowej połowie XX wieku, czyli zaledwie kilkadziesiąt lat temu.

SLH 3/4 2014/2015 | str. 274 
Składnikiem liturgii Wielkiego Piątku była następująca modlitwa:

„(Pro perfidis Judeaeis)

Módlmy się też i za niewierzących żydów: aby Bóg i Pan nasz zdjął zasłonę z ich serc; aby i oni poznali Pana naszego Jezusa Chrystusa. Wszechmogący, wieczny Boże, który w miłosierdziu swojem nikomu, nawet wiarołomnym żydom, przebaczenia nie odmawiasz, wysłuchaj modlitw naszych za lud ten zaślepiony zanoszonych, aby wreszcie poznawszy światło Twej prawdy, którem jest Chrystus, z ciemności swych został wyprowadzony. Przez tegoż Pana [...]” („Wielki Tydzień”, 1937, s. 82).

Tekst ten potwierdzał kanon żydowskich cech. Pierwszą z nich była perfidis, którą wyrażały polskie wyrazy: niewierzący, wiarołomni (w innych tekstach także: niewierni, zdradliwi, niewdzięczni). W sensie teologicznym ten taciński wyraz wskazywał raczej na intelektualny stan Żydów - ich niewiarę w Chrystusa; zgodnie z tym polski tytuł modlitwy brzmiał Za niewierzących żydów. Jednak - pisał ks. Stanisław Musiał - każdy zwykły katolik rozumiał perfidis jako perfidni, czyli 'zdradliwi, wyrachowani, obłudni, złośliwi' itp., a więc w sensie moralnym i dla Żydów wyjątkowo obraźliwym (Musiał, 2001). Lud zaślepiony stanowi kolejne, mocno skonwencjonalizowane określenie Żydów. W tej deprecjonującej interpretacji to właśnie duchowa ślepota, wyrażana również metaforycznie (zasłona w sercu, przebywanie w ciemności), nie pozwoliły Żydom dostrzec w Jezusie oczekiwanego Mesjasza.

Modlitwa Pro perfidis Judaeis jako jedyna z ośmiu modlitw składających się na tę część liturgii Wielkiego Piątku miała nieco inny przebieg niż pozostałe siedem tekstów, w których po pierwszej części wprowadzającej do modlitwy (zapowiadającej, za kogo i o jakie dary Kościół się w niej modli) następowało wezwanie do cichej modlitwy, uklęknięcia, a następnie do powstania. Natomiast w modlitwie za Żydów po wprowadzeniu znajduje się wskazówka:

„Tu nie odmawia się Amen ani nie mówi się wezwania: Oremus - Módlmy się, ani Flectamus genua - zegnijmy kolana, lecz zaraz: Wszechmogący, wieczny, Boże...” („Wielki Tydzień”, 1937, s. 82),

po czym następuje dalsza część tekstu. Odmówienie Żydom cichej modlitwy (której Kościół nie szczędził nawet heretykom i schizmatykom) niewątpliwie dawało wiernym sygnał, że Żydów traktuje się inaczej, gorzej, w sposób dyskryminujący.

W Wielki Piątek odmawiano również psalm pochodzący ze Starego Testamentu (P 139, 2-10, 14), który - jako tzw. prefiguracja - zapowiadał sytuację nowotestamentową. Tekst ten należało rozmieć jako prośbę Chrystusa o ratunek w obliczu męki (antycypacja modlitwy w Ogrójcu). Psalm również łączył z Żydami cały szereg sugestywnych, silnie oskarżających i degradujących określeń: ludzie bezbożni, grzesznicy, pyszni; knuja, wzniecaja walki ustawicznie, usiłuja obalić mię z nóg, rozciagnęli powrozy jako sieć na nogi moje, ukryli sidło na mnie, zastawili zasadzkę, ostrzą języki swoje jako węże, jad żmijowy pod wargami ich.

Budowanie czarnego obrazu Żyda-bogobójcy kontynuowały teksty pasyjne: Gorzkie żale, Droga krzyżowa, Godzinki o Męce Pańskiej oraz pieśni śpiewane przez cały okres

SLH 3/4 2014/2015 | str. 275 
Wielkiego Postu. Zjawisko to możemy zaobserwować na podstawie tekstów zawartych w tzw. książeczce do nabożeństwa pt. Skarbiec modlitw i pieśni wydanej w Katowicach w 1947 roku.

Znamienną ich cechą jest silne eksponowanie aktywności Żydów oraz obfitość wyrażeń wnoszących osąd moralny tej aktywności i samych jej wykonawców. Innymi słowy, na rozmaite sposoby kreuje się taki obraz Żydów, w którym działają oni z nienawiści do Jezusa, okazując przy tym właściwe im okrucieństwo. Okrucieństwo stanowi tradycyjny wątek w chrześcijańskim portretowaniu Żydów, z twórczością pasyjną wiązało się bowiem specyficzne upodobanie do sensualizmu, naturalizmu i swoistej hiperbolizacji w przedstawianiu mąk Zbawiciela. Cechę tę amplifikowano kanonicznymi i niekanonicznymi opisami wyrafinowanych tortur cielesnych i psychicznych, jakich dopuszczali się Żydzi na Chrystusie (Korolko, 2001; Michałowska, 2006, ss. 609 n.).

W modlitewniku z 1947 roku o żydowskim okrucieństwie świadczą przede wszystkim czyny Żydów, które sugestywnie opisują teksty pasyjne. Nazwy działań względem Jezusa pochodzą z leksykalno-semantycznego pola cierpienia, zadawania fizycznego i psychicznego bólu oraz śmierci: lża, naśmiewają się, nazywaja zwodzicielem, opluwaja, szarpią Imię, bija, kopia, rany zadawa, dowlekli za szaty i włosy, krzyż nieść każą, szaty zdzieraja, przybijają nogi i ręce, ukrzyżowany, na śmierć wydany itp. Czyny te opisywane są tak, aby żydowskie okrucieństwo zostało jak najbardziej uwypuklone. Niektóre z czasowników mają w swej strukturze znaczeniowej składnik szczególnie akcentujący użycie siły, gwałtowność, agresję, jak: szarpać, zdzierać.

Większe znaczenie mają jednak określenia modyfikujące charakter obiektów i czynności, o których mówią zdania. Do najczęstszych określeń należą słowa, które reprezentują pojęcie 'okrucieństwo', czyli przede wszystkim przymiotnik okrutny oraz przysłówki okrutnie i z okrucieństwem: „Już Jezusa z miasta wiodą okrutnie żydzi”; „Kiedy Go na górę wiedli okrutni żydzi”; „Okrutni żydzi i szaty z Niego zdzierają”; „Na zabicie okrutne przez żydów szukany”; „z większym okrucieństwem biją kijami, kopią nogami” (cytaty odpowiednio: Skarbiec modlitw i pieśni, 1947, ss. 237, 251, 253, 226, 252). W drugiej kolejności była to zajadłość: „Znów Mu zajadłość żydowska rany zadawa”; „Ale od żydów zajadłych pokoju nie miat”; "I tu [w grobie] od zajadłych żydów nie jest wolny” (cytaty odpowiednio: Skarbiec modlitw i pieśni, 1947, ss. 239, 249, 262). Poza tym portret Żydów tworzyły: złość, zapamiętałość, zawziętość, wściekłość, srogość. Nazwy tych cech i emocji - wysoce nagannych i silnie degradujących pod względem moralnym - nie tylko powtarzały się w tekstach, ale bywały też kondensowane w zdaniach, tworząc nagromadzenia i spiętrzenia, które wyolbrzymiały skalę żydowskiej agresji, na przykład: „Wściekłość żydowska - lud zapamiętały / W swej zawziętości i uporze trwały; „Widząc zawziętą srogość żydowskiej złości" (cytaty odpowiednio: Skarbiec modlitw i pieśni, 1947, ss. 243, 477).

Nazwy tych zbrodniczych cech i afektów wysuwano na pierwszoplanową pozycję podmiotu zdania, co silnie eksponowało bestialstwo Żydów: „Zawziętość żydów stawia 
przed tyrana”; „Znów Mu zajadłość żydowska rany zadawa”; „Wściekłość żydowska [...] Nieść dalej każe krzyż osłabionemu Panu naszemu" (cytaty odpowiednio: Skarbiec modlitw i pieśni, 1947, ss. 235, 239, 243).

Lubowanie się w zadawaniu cierpień, zwierzęcą wręcz krwiożerczość przypisywało Żydom stosowane już od średniowiecza, obiegowe, dehumanizujące wyrażenie porównawcze odwołujące się do obrazu lwa, symbolu dzikiej drapieżności: „wnet się rzucili jako Iwi zaciekli”; ,jako lwi okrutni / Za szaty i włosy Jezusa dowlekli” (cytaty odpowiednio: Skarbiec modlitw i pieśni, 1947, ss. 247, 251).

Szczególną wymowę miało określenie zawarte w Godzinkach o męce Pańskiej: „Przez żydów krwi Twej chciwych jak zbójca pojmany" (Skarbiec modlitw i pieśni, 1947, s. 274). Wątek żydowskiej chciwości krwi Jezusa, który w toku historii przekształcił się w mit chciwości krwi chrześcijańskiej, odegrał istotną rolę w procesie upowszechniania się w Europie tzw. legend o krwi, przynoszących społecznościom żydowskim dramatyczne konsekwencje (pogromy, wypędzenia itp.; zob. Tokarska-Bakir, 2008).

W tekście rozważań do piątej stacji Drogi krzyżowej wprost podsuwano użytkownikom modlitewnika niekorzystną dla Żydów interpretację tego wydarzenia pasyjnego. Jego sens może być niejednoznaczny, gdyż zgodnie z tradycją nazwa tej stacji mówi o pomocy Cyrenejczyka, a więc o czynie wartościowanym pozytywnie. Aby przedsoborowi katolicy nie poczytali jednak Żydom tego faktu za przejaw litości, nadawca wprost steruje uwagą odbiorcy w pożądanym przez siebie kierunku:

„Tu zważajmy nie tyle na współczucie, ile raczej na zawziętość żydowską względem Jezusa. Obawiając się, aby im w drodze osłabiony i zemdlony nie umart, przymuszają Szymona Cyrenejczyka do pomocy w niesieniu ciężkiego krzyża, aby przecież wyrok haniebnej śmierci na Zbawicielu mogli wykonać" (Skarbiec modlitw i pieśni, 1947, s. 244).

Obrazu okrucieństwa Żydów dopełniał szereg innych modyfikatorów intensyfikujących rozmiar męki Jezusa, a przez to krzywd uczynionych przez Jego oprawców. Każde pojawienie się rzeczownika otwiera bowiem miejsce na przydawkę, a wystąpienie czasownika - na jakiś jego okolicznik, miejsca te więc wykorzystywano. Był zatem Jezus pojmany jak zabójca, skazany niewinnie, jakby łotr; krzyż, jaki kazano Mu dźwigać, był bardzo ciężki, miecz, którym Go przebito, okrutny etc.

Warto zauważyć, iż utrwalaniu się negatywnego standardu postrzegania Żydów szczególnie dobrze służyło współwystępowanie w tekście nazw złych cech i emocji z deskrypcjami jednoznacznie wskazującymi na tę właśnie grupę religijno-etniczną. Omówione wyżej pejoratywy pojawiają się bowiem w bezpośrednich związkach składniowych z etnonimami: żydzi, żydowie, żydostwo oraz wyrażeniami ekwiwalentnymi znaczeniowo dzięki obecności przymiotnika żydowski (rota, lud, naród), tworząc z nimi rozliczne frazy i wyrażenia. Wyrazy te towarzyszą więc nazwom czynności składających się na pasję Chrystusa: od żydów szukany, przez żydostwo godzien śmierci obwołany, przez żydów pojmany, żydzi przybijają nogi i ręce, od własnego narodu męczon itp. Konsekwentne łączenie nazw czynności z nazwami sprawców mocno uwypukla aktywność Żydów 
i ich gorliwość w wypełnianiu historycznej roli bogobójców. Wyrażenia zaś takie, jak: okrutni żydzi, od zajadłych żydów, żydowska złość, wściekłość żydowska, zawziętość żydów / żydowska itp., a także Judaszowa chciwość, Judasz zdrajca silnie wiążą ze sobą treści znaczeniowe obu członów, wytwarzając trwałe skojarzenia w świadomości katolickich odbiorców, petryfikując w potocznych wyobrażeniach stereotyp Żyda jako nosiciela tych właśnie - wyjątkowo wstrętnych moralnie - przywar i afektów.

Ważną cechą języka tekstów pasyjnych było użycie praesens historicum. Narracja miała przebieg unaoczniający, istotą tego rodzaju form pobożności jest bowiem współuczestnictwo w rozpamiętywanych wydarzeniach, kontemplacja kolejnych momentów.

Duchowe towarzyszenie Jezusowi w drodze na Golgotę prowadzić miało do wewnętrznego poruszenia, do łez żalu i skruchy, a w końcu - do pokuty i poprawy życia. Z tego względu teksty te posługiwały się zabiegiem językowego minimalizowania dystansu czasowego między tym, co rozgrywało się przed wiekami, a tym, co w religijnym obrzędzie przeżywano hic et nunc. Wiele czasowników opisujących Mękę Pańska, choć odnoszą się do wydarzeń przeszłych, ma gramatyczna formę czasu teraźniejszego, jak w przykładach: „Okrutni żydzi i szaty z Niego zdzierają”; „Kiedy żydzi przybijają nogi i ręce" (cytaty odpowiednio: Skarbiec modlitw i pieśni, 1947, ss. 253, 255).

Sytuacje uczestnictwa w dramacie konstruują też wezwania kierujące uwagę odbiorców (uczestników nabożeństwa) na rozgrywającą się właśnie akcję: „Słuchaj, człowiecze, dekretu, jaki się rozlegał”; „przypatrz się, duszo” i in.

Psychologiczną konsekwencją ujmowania bogobójstwa Żydów jako ich teraźniejszych działań musiało być wyobrażenie, iż są oni wciąż tymi (takimi) samymi, niezmiennie okrutnymi, pełnymi nienawiści katami Chrystusa. Jak czytamy w pracy Joanny Tokarskiej-Bakir, pora Wielkanocy istotnie była okresem zwiększonej nieufności w stosunku do Żydów (Tokarska-Bakir, 2008, s. 198). Nagle przestawali być sąsiadami, z którymi chrześcijan łączą dobre lub złe, ale codzienne stosunki, a zaczynali być „Żydami, którzy ukrzyżowali Chrystusa”. W średniowiecznej Europie Wielki Tydzień oznaczał dla nich zagrożenie - spontaniczne akcje zabijania i demolowania dobytku nie należały do rzadkości (zob. Fry, 2003, s. 40). W mentalności prostych ludzi przedstawieniowa warstwa narracji, mająca nieść ze sobą sensy symboliczne, łatwo - zwłaszcza pod wpływem emocji - ulegała ukonkretnieniu. Szczególnie brzemienne w skutki stało się zrównanie symboliczne, w wyniku którego wszystkich Żydów, każde ich pokolenie zaczęto uważać za tych, którzy realnie są winni sądu Chrystusa i ponoszą konsekwencje odpowiedzi udzielonej Piłatowi: „Krew jego na nas i na dzieci nasze” (Mt 27, 25). To przeświadczenie utorowało drogę antysemityzmowi, a kara, na jaką w oczach wyznawców Chrystusa zasługiwali bogobójcy, dosięgła realnego ciała współczesnych Żydów (Tokarska-Bakir, 2008, s. 184). 


\section{2. Żydzi w tekstach pozaliturgicznych}

Znacznie rozleglejszy obszar manifestowania się stosunku katolików do Żydów stanowią wielorakie, różnogatunkowe teksty niemodlitewne, zarówno te, które również funkcjonują w sferze kultu (kazania i listy pasterskie czytane podczas mszy świętej), jak i te niezwiązane bezpośrednio z rytuałem (wypowiedzi lub przemówienia papieży, biskupów lub innych przedstawicieli Kościoła, podręczniki do katechezy, prasa, publikacje książkowe, internetowe itp.). Wszystkie one w mniejszym lub większym stopniu skierowane są na sferę sacrum, a zarazem na sferę profanum, dyskurs religijny bowiem może nieść ze sobą (i najczęściej niesie) treści wcale niereligijnej natury (por. Garpiel, 2003, s. 49; Skowronek, 2006, s. 41). Oprócz upowszechniania wiedzy religijnej i religijnej moralności, teksty tworzone przez nadawców katolickich mają wpływać także na (świecką) sferę gospodarczą, społeczną, polityczną, obyczajową, kulturalną etc.

Kościół katolicki w Polsce przed ostatnią wojną światową był nastawiony negatywnie wobec Żydów, nie tylko ze względu na tradycyjny sposób postrzegania judaizmu jako błędnej wiary, lecz także z powodu jego zaangażowania w budowę państwa jednolitego wyznaniowo, pod hasłem: Polska dla Polaków-katolików. Historycy tamtego okresu (m.in. Modras, 2004; Pałka, 2006) udokumentowali i opisali liczne przejawy katolickiego antyjudaizmu i antysemityzmu. Świadectwa tekstowe pokazują, że katolicka ambona, a jeszcze bardziej publicystyka („Przewodnik Katolicki”, „Mały Dziennik”, „Rycerz Niepokalanej”, „Gość Niedzielny”, „Pro Christo”), kontynuowały tradycyjne antyżydowskie wątki, pozostając przy ich wersji „kanonicznej” lub poddając je rozmaitym aktualizującym przetworzeniom. Oprócz mitu Żydów-bogobójców wciąż żywotne były tzw. legendy o krwi przypisujące Żydom mordowanie dzieci chrześcijańskich dla pozyskania krwi i organów w celach rytualnych i leczniczych; propagowany głównie przez ks. Stanisława Trzeciaka mit Żydów-spiskowców dążących do panowania nad światem, a „zdemaskowanych" przez tzw. protokoły mędrców Syjonu; mit wrogów wiary i cywilizacji chrześcijańskiej, jawnie i podstępnie działających pod postacią masonerii, socjalizmu, komunizmu i wszelkiej maści sekciarstwa, szkodników rujnujących rodzimą gospodarkę i deprawatorów, prowadzących naród do rozkładu moralnego. Podtrzymywano też dawne mity o psychice Żydów - ukształtowanej przez Talmud lub po prostu im wrodzonej. Szczególną okazję do reprodukowania tych przeświadczeń stanowiły niektóre wydarzenia z życia społeczno-politycznego, jak m.in. dyskusja nad szechita, czyli prawem do rytualnego uboju zwierząt, wykorzystana do podkreślania żydowskiego okrucieństwa czy debata nad nowym prawem cywilnym dająca asumpt do oskarżania Żydów o skłonność do rozpusty. Panujący wówczas kryzys ekonomiczny i powszechna bieda skłaniały natomiast do postrzegania Żydów jako konkurenta, którego należy wyeliminować. Kościół swą praktyką dyskursywną włączył się w realizację „pozytywnego” - jak pisze Damian Pałka - wariantu rozwiązania „kwestii żydowskiej”, który zakładał wyrzeczenie się przemocy, ale dążył do konsolidowania społeczności katolickiej i mobilizowania jej w celu marginalizacji ludności żydowskiej i uzyskania nad nią przewagi w każdej dziedzinie życia (Pałka, 2006, s. 367). 
Język tego dyskursu był przesycony środkami o negatywnym nacechowaniu aksjologicznym i emocjonalnym, budował silnie degradujący obraz Żydów, budzący do nich moralny i fizyczny wstręt. Deprecjonujące było już samo słowo żyd (pisane najczęściej małą literą, chociaż miało oznaczać także narodowość); jego użycie w oczywisty sposób obniżało rangę człowieka zaliczonego do gorszej kategorii (por. Tokarska-Bakir, 2008, s. 42). Stawiane przed nazwiskiem, pełniło funkcję izolującą, jak nakazane przez IV Sobór Laterański naszywki (a w Niemczech najpierw tzw. Judenhut - kapelusz, a później, w czasach nazizmu żółta gwiazda Dawida z czarnym nadrukiem Żyd). Pisano wiec: żyd Marks, żyd Lassale, poeta żydowski Julian Tuwim, drugi żyd z „Wiadomości Literackich”. „Mały Dziennik” z 7 stycznia 1936 roku, protestując przeciwko temu, by doktor Janusz Korczak zajmował się polskimi dziećmi, mówił o nim per dr Goldszmit, odmawiając uznania polskiego nazwiska wybitnego pedagoga.

Więcej negatywnej ekspresji wnosiły derywaty utworzone od słowa Żyd. Użyte w stosunku do osoby dorosłej zdrobnienie Żydek, sugerując niższą wartość tego, co małe, brzmiało pogardliwie. Jeszcze bardziej dewaluujący był żydziak. Obecność Żydów w polskiej gospodarce, polityce czy kulturze nazywano zażydzeniem (obok terminów judaizacja oraz semityzacja). Termin zażydzenie - Verjudung (także Judaisation), oznaczający wydzielenie jednej z kategorii obywateli i uznanie ich aktywności (obywatelskiej, kulturalnej, handlowej itp.) za zagrożenie dla istnienia własnego „narodu”, funkcjonował już wcześniej w nazistowskich Niemczech jako jeden z podstawowych środków wykluczenia5. Polski wariant tego terminu miał tę przewagę nad obcymi: judaizacją i semityzacją, że zachowywał czytelny związek strukturalny ze słowem żyd i „dziedziczył” jego negatywne sensy; być może chodziło również o to, że zażydzenie brzmi podobnie do takich słów, jak obrzydzenie, owrzodzenie; asocjacyjnie zdaje się też należeć do semantycznego pola nazw stanów nieczystości, skażenia, jak zarobaczenie, zawszenie, zaszczurzenie itp. Czasownik zażydzić miał swój antonim konwersyjny odżydzić. Innym derywatem Żyda było słowo zżydzieć. Formę imiesłowową tego czasownika spotykamy m.in. w jednym z artykułów w „Przewodniku Katolickim" (1921, nr 1) mówiącym o zjeździe PPS w Łodzi, gdzie pod czerwonym sztandarem zgromadzić się miała znaczna liczba robotników i zżydziałej inteligencji, czyli tej, która przyjęła „żydowskie” idee. Od słowa żyd ukuto również czasownik żydować, którego użył m.in. ks. Mieczysław Skrudlik w swej wydanej w 1926 roku książce Sekty żydujące w Polsce. Autor udowadniał w niej, że sekta badaczy Pisma Świętego jest żydowską komórką w chrystianizmie, dążącą do przyspieszenia panowania Żydów nad światem (Pałka, 2006, s. 159). Żydować oznaczało więc 'działać w interesie Żydów, realizować ich cele’.

Szczególną metodą degradacji Żydów było obniżanie ich statusu ontycznego przez animalizację, czyli stosowanie metafor mówiących o ludziach jak o zwierzętach

4 Pisanie i wymawianie słowa żyd przy nazwisku było urzędowo nakazanym środkiem „ochrony” niemieckiej wspólnoty narodowej przed zetknięciem się z Żydami, elementem Lingua Tertii Imperii, języka Trzeciej Rzeszy (zob. Klemperer, 1989, s. 88).

5 Słowa Verjudung użył np. Martin Heidegger w liście polecającym z 1929 roku, gdzie stwierdził, iż lepiej popierać ludzi wyrosłych na rodzimej glebie (echt bodenständige) niż dopuszczać do „zażydzenia” niemieckiego życia intelektualnego (zob. Sieg, 1989, s. 50). 
(por. Krzeszowski, 1998, s. 97). W jednym z artykułów w „Przewodniku Katolickim” (1939, nr 166) pisano, że żydzi warczą (na prawdę Bożą), w innym, że bełkoca przez polskie radio („Przewodnik Katolicki”, 1939, nr 97). Bełkot nie jest wprawdzie dźwiękiem wydawanym przez zwierzę, ale nie jest też mową ludzką, wiec słowo to również działało dehumanizująco. Ks. Wiśniewski nazwał Polskę plugawym żerowiskiem żydowskim („Pro Christo”, 1933, r. 9, s. 513), a żerowisko to 'miejsce, w którym żerują zwierzęta' (SJPSz). Stosowanie obrazu zwierząt (psa, świni, kozła) w celu klasyfikacji członków grupy innej niż własna jako istot niebędących (w pełni) ludźmi jest mocno zakorzenione w tradycji polemik chrześcijańsko-żydowskich (zob. Tokarska-Bakir, 2008, s. 349 n.).

W sposób obniżający wartość nazywano też wszelkie obiekty należące do Żydów: szpargały, piśmidła, filmidła, sztuczydła. Nazwy żydowskich obiektów często występowały z deprecjonującą przydawką, wywołującą nieprzyjemne wrażenia estetyczne, jak obrzydliwy, wstrętny, śliski oraz szczególnie często występujący przymiotnik plugawy (np. plugawy wyrób żydowski, plugawe piśmidła, „skarby” z plugawych kuźni żydowskich, plugawe żerowisko żydowskie). Funkcjonował też rzeczownik plugastwo. Środki tego rodzaju pojawiały się głównie przy okazji opisywania żydowskiej deprawacji, jak na przykład w poniższym fragmencie z „Przewodnika Katolickiego”:

„Oni również [Żydzi] wydają t.zw. tygodniki powieściowe. Można nabyć ten plugawy wyrób żydowski w każdym kiosku. [...] Treść zazwyczaj śliska, obrzydliwa: mordy, zdrady, kradzieże, pieprzne sceny miłosne, uwodzenia. „Bohaterem” jest zwykły bandyta, który normalnie powinien gnić w kryminale, a nie zaprzątać umysłów polskiej młodzieży. [...] Żydkowie zaś z warszawskich Nalewek, gdzie drukuje się to plugastwo, zacierają z uciechy ręce” (,Przewodnik Katolicki”, 1939, nr 97).

Czasopisma katolickie - za pomocą odpowiednich wyborów leksykalnych - budowały też trwałe skojarzenia Żydów z brudem i brzydotą. Przez wytworzenie odruchu odrazy usiłowano zmotywować katolickich czytelników do bojkotu żydowskiego handlu i usług. Pisano więc na przykład, że w piekarniach żydowskich panuje brud i robactwo („Mały Dziennik”, 1936; cyt. za: Modras, 2004, s. 25), że sprzedają alkohol, którym przedtem zmyli oparszała głowę żydziaka, albo zepsute kiszki (kiełbasę), które lekarz weterynarii kazał wyrzucić do dołu kloacznego („Polak-Katolik”, 1926; cyt. za: Pałka, 2006, s. 152). Pierwszy numer „Przewodnika Katolickiego” z 1939 roku nawoływał: „W nowym roku wymiećmy z polskiego domu żydowskie śmieci!” („Przewodnik Katolicki”, 1939, nr 1).

Nieuczciwość w handlu nazywano brudną konkurencją. Odwoływano się, jak widać, do systemu klasyfikacyjnego opartego na opozycji czysty-nieczysty, obliczonej na separację i wykluczenie wyznawców judaizmu poza obręb własnej wspólnoty (zob. Tokarska-Bakir, 2008, s. 344). Jako splamienie chrześcijańskiej przestrzeni postrzegano także działalność Żydów w dziedzinie kultury, obyczaju, polityki. Jak donosił „Przewodnik Katolicki”:

„Pisma te sfabrykowane w żydowskich drukarniach, szeroką fala zalewają naszą Ojczyznę, psują i zatruwają obyczaje wśród młodzieży, która nieraz za skradzione rodzicom grosze nabywa ten jad żydowsko-masoński w kioskach” („Przewodnik Katolicki”, 1939, nr 190).

SLH 3/4 2014/2015 | str. 281 
Skażenie miało też charakter zapachowy, przed ostatnią wojną wciąż bowiem był jeszcze żywy mit o żydowskim fetorze. Ks. Nikodem Cieszyński na pytanie, kto w polskim Sejmie jest odpowiedzialny za „komunistyczne wichrzenie”, odpowiedział: „nietrudno zgadnąć, bo ogólnie to już wiadomo od czasów Swetoniusza, że cuchnąca i wiecznie kłócąca się zgraja to Żydzi” (cyt. za: Pałka, 2006, s. 174). Nie brakło i skażenia sfery wzrokowej: w kreowanym przez katolicką prasę krajobrazie polskich miast i wsi uliczki żydowskie były brudne, a żydowskie bóżnice szpetne.

Negatywnie zabarwione słownictwo znajdowało zastosowanie w opisach wszelkich aspektów żydowskiej działalności. W handlu było to: szachrować, szmuglować, frymarczyć, stosować triki. Oskarżenia o spiskowanie w skali lokalnej i światowej łączyło się z użyciem słów wskazujących na zorganizowaną przestępczość, jak szajka, klika, zgraja, mafia. Na płaszczyźnie moralno-obyczajowej Żydów deprecjonowały zaś tak silnie degradujące pejoratywy, jak szumowiny czy wszetecznicy.

Przedwojenny dyskurs katolicki ustanawiał jeszcze jedno bardzo istotne skojarzenie, mające dobrze się zakorzenić w świadomości Polaków-katolików. Jest to skojarzenie, którego utrwalaniu służył przede wszystkim stały i wysoce frekwentywny związek: niebezpieczeństwo żydowskie, ale także inne połączenia wyrazów: żydzi (lub żydowski) ze słowami oznaczającymi zagrożenie: niebezpieczny, zagrażać, groźny, grożący. Zgodnie z poetyką tego dyskursu niebezpieczeństwo to wielorako wyolbrzymiano, nadając mu (co widać zwłaszcza w listach pasterskich kardynała Augusta Hlonda) rozmiar zguby, zagłady całej ludzkości. Przedwojenne media katolickie systematycznie i w sposób niezwykle sugestywny przedstawiały potworności komunizmu (zob. Makuchowska, 2011, s. 193 n.), z którym Żydów również konsekwentnie łączono (o czym świadczył choćby obieg takich wyrażeń, jak żydokomuna, judeo-komunistyczny czy koniunkcja żydowski i bolszewicki). Sięgano więc po tak niezawodny środek perswazji, jakim jest strach. Typowa dla ówczesnego dyskursu metaforyka militarna służyła mobilizacji przeciwko Żydom, z którymi trzeba walczyć nie tylko w obronie wartości chrześcijańskich, ale także o unarodowienie sfery gospodarczej w kraju. Dla podbudowania morale czytelników „Mały Dziennik” czy „Przewodnik Katolicki” każde dokonanie na tym polu przedstawiały jako zwycięstwo w walce nad przeważającymi siłami wroga (por. Modras, 2004, s. 231). Skalę zagrożenia podkreślały środki konstruujące obraz ofensywy Żydów - ich działania to ataki, a podstępny charakter tych działań ewokowało słowo czyhać.

Środki językowe wykorzystywano także do kreowania własnej wspólnoty wyznaniowo-narodowej i separowania jej od Żydów oraz do zaznaczania swego stanu posiadania. Temu, co żydowskie, przeciwstawiano to, co chrześcijańskie, katolickie i polskie, utrwalając przekonanie, że Żydzi stanowią w państwie element obcy nie tylko religijnie, ale i etnicznie. Widzimy to na przykład w konstatacji: „Żydzi w Polsce mają większe prawa w zakresie szkół niż Polacy” („Przewodnik Katolicki”, 1934, nr 642).

Funkcję budowania opozycji: „polskie i katolickie” versus „żydowskie” pełniły przymiotniki chrześcijański, katolicki i polski oznaczające 'nieżydowski', które (osobno lub jako

SLH 3/4 2014/2015 | str. 282 
koniunkcja polski i katolicki) współwystępowały z nazwami różnych elementów rzeczywistości gospodarczej, społecznej i kulturalnej (miasta, wsie, banki, młyny, sklepy, składy, tartaki, fabryki, kupcy, rzemieślnicy, krawcy, dentyści, urzędy, starostwa, nadleśnictwa, szkoły, filmy, książki itp.). W przedwojennych tekstach spotykamy więc dziwnie dziś brzmiące wyrażenia typu: katolicki sklep galanterii, katolicki sklepik bławatny, dorożka chrześcijańska itp. Przymiotniki te pojawiały się najczęściej w takich kontekstach, w których - wprost lub pośrednio - zachęcano czy wręcz zobowiązywano do działań mających na celu sukcesywne zwiększanie polskiego stanu posiadania kosztem Żydów, na przykład:

„Niech stanie w szeregu tych, którzy w Polsce pragną mieć polskiego katolickiego kupca, polskiego katolickiego rzemieślnika i takiegoż fabrykanta! [...] Czuwajcie wszyscy, by grosz polskich katolickich rodzin zanoszony był do polskich katolickich kupców i rzemieślników!

Kto Związek Polski popiera, ten Polskę kolonizuje, ten Polsce daje rzemieślnika, kupca i przedsiębiorcę Polaka katolika!” („Przewodnik Katolicki”, 1937, nr 592).

Sumując, należy stwierdzić, iż przedwojenny dyskurs o Żydach wyrażał z jednej strony odwieczną niechęć do narodu, który odrzucił Mesjasza, z drugiej strony miał on przynieść konkretne efekty perlokucyjne - skutecznie zachęcać do działań, jakie katoliccy nadawcy wskazywali swym odbiorcom. Hasła wzywające do bojkotu żydowskich towarów i usług, odsunięcia Żydów od edukacji i kultury, stwarzania im tak niekorzystnej sytuacji w Polsce, by poczuli się zmuszeni do jej opuszczenia, mogły budzić wśród katolickich odbiorców niepokój moralny. Dlatego definiowano je jako samoobronę - oczywistą i konieczną w sytuacji ataku wroga - dla ratowania siebie, własnej rodziny, ojczyzny, prawdziwej wiary. Działania przeciwko Żydom postulowane przez katolickich nadawców stawały się dzięki temu obowiązkiem moralnym, patriotycznym i religijnym.

\section{Stan posoborowy}

\section{Zmiany w tekstach liturgicznych}

Jeszcze przed soborem, w pierwszej liturgii wielkopiątkowej swojego pontyfikatu Jan XXIII polecił skreślić z rytuału modlitwę Pro perfidis Judaeis, a od 5 lipca 1959 roku zmiana ta na mocy dekretu Kongregacji Obrzędów zaczęła obowiązywać w całym Kościele. Nowa wersja tej modlitwy, pozbawiona negatywnych treści, pojawiła się w Mszale w 1970 roku. Przyjęta przez Sobór Watykański II Deklaracja o stosunku Kościoła do religii niechrześcijańskich „Nostra aetate” w punkcie czwartym zawiera stwierdzenie, które miało ostatecznie położyć kres absurdalnemu oskarżaniu wszystkich Żydów o śmierć Jezusa. W samym dokumencie na oznaczenie rzeczywistych sprawców tego historycznego faktu użyto wyrażenia: władze żydowskie, czyli deskrypcji partytywnej oznaczającej (określoną) część wskazanej zbiorowości, a nie jej całość: „to, co popełniono podczas Jego męki, nie może być przypisane ani wszystkim bez różnicy Żydom wówczas żyjącym, ani Żydom dzisiejszym”. Dalej dokument ten oświadcza, iż: „Chociaż Kościół jest 
nowym Ludem Bożym, nie należy przedstawiać Żydów jako odrzuconych ani jako przeklętych przez Boga, rzekomo na podstawie Pisma Świętego" (Nostra aetate, 2009).

Antycypując niejako myśl soborową jeszcze przed jego rozpoczęciem usunięto dodatek do ułożonej przez Leona XIII modlitwy do serca Jezusowego, w którym była mowa m.in. o utraconym przez Izrael wybraństwie. Z chwilą przyjęcia Deklaracji "Nostra aetate" wszelkie nawiązania do tych dwóch tez - uniwersalnej odpowiedzialności Żydów za bogobójstwo oraz końca ich historii jako Narodu Wybranego - już nie miały prawa nigdy i nigdzie się pojawić.

W polskim tłumaczeniu Mszału rzymskiego z 1986 roku nowa, obowiązująca do dzisiaj, wersja wielkopiątkowej modlitwy za Żydów zawiera sformułowania świadczące o tym, iż translacja tego tekstu nie została dokonana z całą troską o wierność łacińskiemu pierwowzorowi i niesionym przezeń sensom. Oto jak brzmi ta modlitwa:

„Módlmy się za Żydów, do których przodków Pan Bóg przemawiał, aby pomógł im wzrastać w miłości ku Niemu i wierności Jego przymierzu. Wszechmogący, wieczny Boże, Ty dałeś swoje obietnice Abrahamowi i jego potomkom; wysłuchaj łaskawie prośby swojego Kościoła, aby lud, który niegdyś był narodem wybranym, mógł osiągnąć pełnię odkupienia. Przez Chrystusa, Pana naszego".

Jak wyjaśnia ks. S. Musiał, zdanie „do których przodków Pan Bóg przemawiał” powinno brzmieć: „do których Pan Bóg nasz pierwej przemawiał” (zgodnie z łacińskim oryginałem: „ad quos prius locutus est Dominus Deus noster”) (Musiał, 2001). Drugie złe tłumaczenie, a nawet skandaliczne, jak wyraził się autor tej opinii, to zdanie: „który niegdyś był narodem wybranym”. Łaciński oryginał składa się z trzech słów: „populus acquisitionis prioris”. W dosłownym przekładzie brzmią one: „lud wcześniejszego nabycia”, co można oddać lepiej: „lud wcześniej nabyty na własność” (domyślnie: „przez Ciebie, Boże”) albo: „lud, który nabyłeś jako swoją pierwszą własność”. Przysłówek niegdyś jaskrawo więc przeczy nauczaniu ostatniego soboru, dezaktualizując przymierze Żydów z Bogiem jako ważne jedynie w przeszłości.

Dopełniając wątku należy wspomnieć, iż w 2007 roku papież Benedykt XVI przywrócił do użytku stary Mszał, tzw. trydencki, przeznaczony do liturgii w języku łacińskim (jak przed soborową reformą), a z nim - także przedsoborowy tekst modlitwy za Żydów. Fakt ten wywołał wiele protestów, dlatego dokonano pewnych zmian, które uspójniły tę modlitwę z nauczaniem soboru, ale nie zadowoliły wyznawców judaizmu. Teolodzy żydowscy widzą w niej m.in. wezwanie do nawracania Żydów jako tych, którzy tkwią w niewłaściwej wierze, co jest dla nich degradujące.

W innych tekstach pasyjnych, jak Droga krzyżowa i pozostałe nabożeństwa, pewne zmiany wprowadzono niemalże tuż po wojnie. Przykładem jest wydanie z 1949 roku bardzo popularnej na Śląsku Drogi do nieba, gdzie widzimy zasadnicze różnice w stosunku do zawartości przedwojennej wersji tego modlitewnika. Całkowicie zniknęły etnonimiczne leksemy Żyd, Żydzi, Żydostwo, a nazwy te konsekwentnie zastąpiono wyrazami kaci, zbójcy, mordercy, pospólstwo, tłum.

SLH 3/4 2014/2015 | str. 284 
We współczesnych modlitewnikach również unika się etnonimu Żydzi (lub jego ekwiwalentów, jak np. rota żydowska), stosując rzeczowniki typu kaci, wrogowie (np. Modlitewnik codzienny z 2006 roku) lub żołnierze (m.in. w jednej z dróg krzyżowych dla dzieci). W miejsce dawnych kolokacji: zawziętość/zajadłość żydowska wstawiono związki: zawziętość ludzka, zajadłość oprawców (Droga do nieba z 1996 roku). W ten sposób w ogóle ucieka się od wskazywania narodowej przynależności katów Jezusa, co jest rozwiązaniem o tyle wygodnym, iż ewentualne precyzacje, że byli to wprawdzie Żydzi, ale tylko pewna ich grupa, byłyby bardzo trudne ze względów stylistycznych (nie są to teksty naukowe i nie da się w nich konsekwentnie zachowywać ścisłości terminologicznej).

Innym rozwiązaniem, będącym wynikiem nie tylko powierzchownych „retuszy”, ale pogłębionej refleksji teologicznej, jest całkowita rezygnacja z opisu męki, jak w modlitewniku dla młodzieży Z Bogiem przez życie (Chabiński, 2004, s. 248), gdzie mówi się wyłącznie o sensach duchowych i moralnych, jakie dla człowieka-użytkownika tego tekstu wynikają z określonego wydarzenia pasyjnego:

„Przecież nie o to chodzi, żebym tę scenę rozważał, ale bym ciągle na nowo uczył się, jak podejmować solidarnie z drugim człowiekiem jego życiowy trud, wierząc, iż to jest krzyż Chrystusowy - znak zbawienia" (Chabiński, 2004, s. 248).

Modlitewnik ten w myśl idei soborowych uwypukla teologiczne znaczenie męki Chrystusa, wychodzi więc poza ramy historycznych realiów do współczesności dzisiejszych chrześcijan. Biblijne wydarzenia z Golgoty zostają przedstawione jako jeden z wariantów aktu Odkupienia; ten, który dokonał się w określonym czasie i miejscu, ale możliwe były także inne warianty, inny czas i inne miejsce. Udział Żydów w tamtym wydarzeniu był zatem tylko konsekwencją historyczności życia i śmierci Jezusa, nieuniknioną, ale też i nieistotną, bo w innym czasie i w innym miejscu ich rolę spełniłby ktoś inny. W poniższym tekście nieważność tożsamości oprawców wyrażają bezosobowe formy czasowników:

„Dzisiaj nie poświęcono by Ci tyle czasu. Skazano by Cię - oszczędzając belek i gwoździ na głodową śmierć w bezimiennej masie ludzi trzeciego świata albo wysłano na niesprawiedliwą wojnę. Może zatruwano by Cię powoli, lecz systematycznie: dymem, hałasem, intrygami, brakiem zainteresowania tym, co mówisz" (Chabiński, 2004, s. 251).

Soborowa Deklaracja zwraca również uwagę, że Chrystus dobrowolnie, z miłości, podjął swą zbawczą mękę. W modlitewniku Z Bogiem przez życie znajdujemy tekst odpowiadający i temu stwierdzeniu. Wyróżnioną pozycję agensa, wcześniej zajmowaną przez żydów, tutaj zajmuje Jezus i Jego działania, które mają charakter pozytywny, skierowany na dobro człowieka. Centrum pasyjnego obrazu nie stanowi więc Chrystus jako ofiara żydowskiej (ani w ogóle ludzkiej) podłości, lecz postać Odkupiciela z własnej woli podejmującego czyn miłości do ludzi. Podkreślają to czasowniki nazywające podmiotowe, wolicjonalne działanie Jezusa, a także rzeczownik zadanie (we frazie podjać zadanie), który zdecydowanie nie mieści się już w scenariuszu katowania bezwolnej ofiary:

SLH 3/4 2014/2015 | str. 285 
„Zależało Ci na tym, by tę bolesną drogę odbyć do końca. Chciałeś być konsekwentny, wierny zadaniu, jakiego się podjąłeś. Wiedziałeś, ile od tego zależy w życiu ludzi” (Chabiński, 2004, s. 250).

Powyższe fakty świadczą więc o tym, że w tekstach oficjalnych, związanych ze sprawowaniem kultu, a więc sferą poddaną ścisłej kontroli Kościoła, wiele uczyniono dla usunięcia tradycyjnego, negatywnego obrazu starszych braci w wierze (zob. Makuchowska, 2011, ss. 22-23).

Mimo to, trudno za niezasadny uznać zarzut formułowany m.in. przez Daniela J. Goldhagena, że nie są to zmiany wystarczające, gdyż katolicka liturgia wciąż transmituje obraz Żydów, którzy zabili Chrystusa (Goldhagen, 2005). Raczej nie można przyjąć, że wszyscy wierni skupiają się wyłącznie na religijnym sensie wydarzeń zbawczych, nie czerpiąc przy tym wiedzy podtrzymującej negatywne stereotypy. Zwłaszcza iż nie należy do wielkopostnego zwyczaju taka eksplikacja tekstów liturgicznych (dokonywana np. podczas kazań), która skutecznie „unieszkodliwiłaby” degradujący Żydów przekaz. Zdarza się natomiast, że na przykład w kazaniu pasyjnym w czasie Gorzkich żalów słychać antyżydowskie akcenty, są też duchowni, dla których opis Męki Pańskiej czytany w kościele w Niedzielę Palmową i Wielki Piątek jest „koronnym” dowodem na winę wszystkich Żydów za śmierć Jezusa6 (włączając w to Jana Brzechwę, którego nie życzył sobie na patrona szkoły proboszcz jednej z polskich wsi) (zob. Czajkowski, 2000, s. 174).

\section{Zmiany w tekstach pozaliturgicznych}

Tekstowe świadectwa pozytywnego nastawienia do Żydów najłatwiej znaleźć w przestrzeni dyskursywnej Kościoła powszechnego, w oficjalnych dokumentach, w przemówieniach papieskich i wypowiedziach hierarchów kościelnych reprezentujących instytucje powołane do dialogu, pewnego grona rzeczników tegoż dialogu, teologów i publicystów, duchownych i świeckich, otwartych na spotkanie z innymi wyznaniami i religiami.

Przede wszystkim należy tu wspomnieć o aktach przeprosin pod adresem Żydów. Pierwszy z nich dokonat się w Deklaracji „Nostra aetate”; o przebaczenie win prosit Jan Paweł II w swych dokumentach i przemówieniach. Z jego pontyfikatem związane są dokumenty pokutne wydane przez Stolicę Apostolską (Pamiętamy. Refleksja nad Szoah z 1998 roku oraz Pamięć i pojednanie. Kościót i winy przeszłości z roku 2000). W wypowiedziach tych nie ma podstawowego dla przeprosin performatywu przepraszać, a za akt skruchy uznano frazę Kościół opłakuje oraz modlitwę do Boga o przebaczenie win. Przyznano się do aktów nienawiści, prześladowań, przejawów antysemityzmu, przysporzenia cierpień.

6 Zdaniem Goldhagena istota problemu tkwi w fakcie, że to ewangelie (zwłaszcza Jana i Mateusza) stanowią źródło negatywnego stereotypu Żydów, przedstawianych nie tylko jako bogobójcy, lecz również jako synowie diabła i jego ziemskie wcielenie. Nic więc radykalnie się nie zmieni, jeśli - twierdzi autor - chrześcijanie (a przede wszystkim Kościół katolicki, do którego autor w szczególności kieruje ten postulat) nie zdobędą się na korekty. 
Do najważniejszych rysów nowego, pozytywnego modelu komunikacji katolików z Żydami należy też użycie środków wyrażających wspólnotę, a przez to stwarzanie jej w rzeczywistości pozajęzykowej. Eksponowanie wspólnoty odbywa się we wszystkich nurtach dialogu ekumenicznego i międzyreligijnego, ale w tym wypadku mówi się o szczególnym charakterze owej więzi. Religię żydowską określa się jako rzeczywistość wewnętrzna dla chrześcijaństwa (Muszyński, 1990, s. 14). Jak wyjaśnia teolog, więź tę Kościół uczynił elementem konstytutywnym swego istnienia. Już nigdy bez wyrzeczenia się samego siebie nie będzie mógł w jakikolwiek sposób zwrócić się przeciwko Żydom, odwrócić się od nich albo sprzymierzyć z ich nieprzyjaciółmi (Wenzel, 2007, s. 131).

Wysoką częstotliwość mają więc wyrazy takie, jak więź, więzy, związki, bliskość, łączyć, wiązać, zbliżać, zespolić, związany, zespolony, bliski. Towarzyszą im środki intensyfikujące stopień owej więzi, najczęściej wyrazy z pola semantycznego głębi: głęboka więź, głębokie więzy, niezgłębiona więź, coraz głębiej związany, pogłębiać więzy, a także przymiotnik trwały (trwała wieź, trwałe więzy), który rzutuje zarówno na obraz przeszłości, jak i przyszłości, suponując, że ta więź istniała od początku i na zawsze pozostanie nierozerwalna. Obie te przydawki współwystępują czasem ze sobą: „[...] różne formy współpracy dla postępu ludzkiego zainspirowane naszym wspólnym dziedzictwem biblijnym stworzyły głębokie i trwałe więzy miedzy Żydami i katolikami" (Chrostowski \& Rubinkiewicz, 1990, s. 101).

Stan rzeczywistej i postulowanej wspólnoty wyraża się też za pomocą takich wyrazów, jak wspólny, wspólnie, wspólnota. Wykorzystuje się funkcję integrującą przysłówka razem, który pojawia się zwłaszcza w kontekście treści wyrażających zachętę do wspólnego zaangażowania się na rzecz dobra drugiego człowieka: „Mamy tak wiele wspólnego. Razem możemy tak wiele uczynić dla pokoju, sprawiedliwości, dla bardziej ludzkiego i braterskiego świata"7.

Istotną rolę odgrywają wyrazy wzajemny i wzajemnie oraz leksemy z przedrostkiem wspót- (wspótpraca, wspótdziałanie). Bardzo ważne są też formy pierwszej osoby liczby mnogiej, które konstruują obraz żydów i chrześcijan jako jednej zbiorowości. Nadawcy stosują zaimek osobowy my, odnosząc go do własnej grupy i jednocześnie do wyznawców judaizmu. Wiąże się z tym użycie pierwszoosobowych form czasowników, integrujących obie społeczności na poziomie składniowym i semantycznym, np. mamy wspólna tradycje; zadania, które mamy wspólnie podjać; pogłębiamy więzy przyjaźni i zaufania miedzy nami i jesteśmy dla innych znakiem nadziei na przyszłość. Poczucie jedności skutecznie buduje także zaimek dzierżawczy nasz, podstawowy wykładnik tzw. kategorii bliskości (zob. Puzynina, 1992, s. 174; Bralczyk, 2007, s. 150), na przykład nasze wspólne dziedzictwo, nasze kontakty, nasz dialog, nasze spotkanie, nasza odpowiedzialność, nasze religijne zobowiązania i nasze powołanie, nasze przekonania, nasze codzienne postępowanie itp.

Jedność wyraża też metafora dziczki oliwnej, której użyto w Deklaracji „Nostra aetate” i którą chętnie powiela się w innych tekstach: „[...] Kościół [...] czerpie pokarm z korzenia

7 Przemówienie Jana Pawła II wygłoszone do naczelnych rabinów Izraela w Jerozolimie 23 marca 2000 roku. 
dobrej oliwki, w którą wszczepione są gałązki dziczki oliwnej narodów" (Nostra aetate, 2009, pkt 4).

Metafora drzewa oliwnego miesza się i splata z obrazem krzewu winnego. Dla przekazania poznawczych i wartościujących sensów tych obrazów ważny jest fakt, że są to metafory roślinne, które ewokują organiczną strukturę typu część - całość (por. Krzeszowski, 1998, s. 93). Eksponują więc one ścisły związek obu religii, stanowiących dwie części tego samego organizmu. Przenośne użycie wyrazów: korzenie, zakorzeniony, zakorzenić się nie zawsze wywołuje biblijny obraz oliwki czy winorośli, lecz uczestniczy w orzekaniu, że judaizm stanowi początek chrześcijaństwa.

Inną ważną domeną źródłową metafor kreujących ścisłą więź między żydami i chrześcijanami jest rodzina. Eksponuje się fakt bycia dziećmi wspólnego Ojca, nie tylko Boga, ale także Abrahama. Abraham jest dziś przywoływany jako postać znajdująca się u korzeni judaizmu, chrześcijaństwa oraz islamu (Petuchowski \& Thoma, 1995, ss. 25, 28). Z posiadania wspólnego ojca w naturalny sposób wynika relacja braterska między chrześcijanami a żydami. Podczas historycznej wizyty w Synagodze Większej (13 kwietnia 1986 roku) Jan Paweł II powiedział do Żydów: „Jesteście naszymi umiłowanymi braćmi i - można powiedzieć - naszymi starszymi braćmi”.

Wiele środków językowo-tekstowych zaangażowanych jest w chwalenie Żydów, budowanie ich pozytywnego wizerunku. Wbrew tzw. teorii zastępstwa, głoszącej jakoby rola Izraela w planie Opatrzności wyczerpała się z chwilą narodzin chrześcijaństwa, mówi się o tym, iż Lud Starego Przymierza, żyjący dzisiaj, nadal pełni zadania wyznaczone mu przez Boga. Myśl tę podkreślają formy czasu teraźniejszego czasowników, na przykład: „Oto orędzie wiary i prawdy, które przez całą historię niesiecie i świadczycie w świetle Słowa i Przymierza Bożego" (Chrostowski \& Rubinkiewicz, 1990, s. 228).

Oczywiście nie wszystkie zdania wyrażające pochwałę Żydów mają predykaty w czasie teraźniejszym, mówi się bowiem także - i to wiele - o ich zasługach dla chrześcijaństwa położonych w przeszłości, jak: „Odnośmy się z uszanowaniem do Narodu Wybranego za to, że przekazał nam wielki dar, wiedzę o Jedynym Bogu, monoteizm w odróżnieniu od politeizmu, wielobóstwa. Co więcej, właśnie Żydzi widzieli w Bogu swojego Ojca [...]" (Bukowski, 2004, s. 53).

Chwalenie wyznawców judaizmu angażuje nazwy wielu wartości wysoko usytuowanych w hierarchii aksjologicznej obu religii, jak: prawda, wierność, świadectwo wiary, szacunek ożywiony atmosferą modlitwy, dyspozycyjność w słuchaniu i posłuszeństwie Słowu Bożemu, czczenie z głęboką pobożnością Pisma Świętego, stałe potwierdzanie jedności Boga, Jego ojcostwa i miłosierdzia, angażowanie się w realizację sprawiedliwości, pokoju i innych wartości etycznych itp. Wartość żydowskiej tradycji podkreśla tak pozytywnie nacechowane wyrażenie, jak duchowe bogactwa judaizmu czy nawet skarby duchowego bogactwa. Wkład judaizmu w chrześcijaństwo profiluje się jako dar przekazany wyznawcom Chrystusa. Kultura religijna Żydów jest tym samym ujmowana przez nadawców katolickich jako coś cennego, posiadającego istotną wartość, jako 
bogactwo, majątek (por. definicje leksemów dziedzictwo, spadek w słownikach polszczyzny).

O szacunku dla Żydów mówi się w trybie powinnościowym: Kościół katolicki zobowiązuje swoich wyznawców do wypracowania w sobie pozytywnych uczuć i postaw wobec wyznawców judaizmu. Nazwy projektowanych emocji i postaw pojawiają się bezpośrednio w tekstach i uczestniczą w otwartym formułowaniu apeli o ich okazywanie: odnośmy się z uszanowaniem do Narodu Wybranego; nasza postawa do religii żydowskiej ma być postawą najwyższego szacunku.

Szczególnie ważnym i specyficznym dla tego dyskursu jest wątek Zagłady, rozwijany zwłaszcza w nauczaniu Jana Pawła II. Według indeksu przedmiotowego dla wszystkich tekstów tego papieża tworzących jego nauczanie o żydach i judaizmie z lat 1979-1989 słowa takie, jak Szoah, Holokaust, eksterminacja, ludobójstwo, unicestwienie, zagłada, pojawiły się na 50 stronach (z 160 stron całości). Uznano, iż tragedia, jaka spotkała naród żydowski, jest jego tak traumatycznym doświadczeniem, że w kontaktach z Żydami nie sposób o niej nie mówić. Nadawcy chrześcijańscy nie mogą milczeć tym bardziej, że to właśnie w kręgu kultury chrześcijańskiej doszło do zagłady sześciu milionów osób tylko dlatego, że byli Żydami. Stawia to chrześcijaństwo przed zadaniem odzyskania wiarygodności w ich oczach (por. Fry, 2003, s. 59), jak też przede wszystkim przed koniecznością głębokiej refleksji nie tylko nad dokonaną zbrodnią, ale i nad własnym stosunkiem do niej (Zuberbier, 1990, s. 21). Dialog chrześcijańsko-żydowski bez poruszania tematu Holokaustu jest więc po prostu niemożliwy.

Mówienie o Zagładzie wprowadza do tekstów słownictwo martyrologiczne (ból, łzy, cierpienie, męczeństwo, straszliwe doświadczenie, tragedia, katastrofa, zagłada, hekatomba, Kalwaria). Wymiar cierpienia przekraczający ludzką zdolność pojmowania oddają słowa szczególny (szczególna miara wyniszczenia, szczególna zbrodnia), pojęcie otchłani (otchłań Szoah), przymiotniki zanegowane: nieopisane, niezmierzone, niewypowiedziane (cierpienia, zbrodnie), wyrażenia typu: brak słów, by wyrazić, konstrukcje metaforyczne, jak przeogromne morze bólu, morze cierpień $i$ łez. Papież operował też pojęciem antysemityzm, potwierdzając realny charakter oznaczanych nim zjawisk, formułując zarazem potępienie dla tego rodzaju postaw, nazywając je grzechem. Apelował o całkowite przezwyciężenie uprzedzeń narodowościowych czy rasowych, nadając swym wypowiedziom tryb modalności deontycznej (trzeba, musimy, nie wolno) lub postać otwartego, usilnego apelu (wyrażonego za pomocą predykatów wzywać, prosić). Stawiał więc odbiorców, przede wszystkim każdego katolika, w stan zobowiązania.

Wszystko to, jakkolwiek niewątpliwie stanowi wielki postęp w relacjach między chrześcijanami i żydami, budzi poczucie niedosytu. Refleksja nad związkiem między chrześcijaństwem a krzywdami, które przez wieki spotykały społeczności żydowskie w całej Europie, nie sięgnęła samego jądra problemu, jakim są antyżydowskie treści należące do kanonu chrześcijańskiej doktryny (przede wszystkim ugruntowana w ewangeliach rola Żydów jako zabójców Boga, zob. Tokarska-Bakir, 2008). Zarzuca się też Kościołowi, iż 
w istocie nie podjął bezstronnej, rzetelnej i dogłębnej analizy wpływu swego nauczania na świecki antysemityzm, w tym przede wszystkim antysemityzm nazistowski, który doprowadził do Holokaustu (zob. Goldhagen, 2005). Przepraszaniu za winy nie towarzyszą autentyczne wysitki dotarcia do prawdy w kwestii grzechów zaniechania lub nawet czynnego udziału hierarchii Kościoła w eksterminacji Żydów w latach nazizmu (w tym także chodzi o postawę papieża Piusa XII).

W oficjalnym dyskursie Kościoła daje się zauważyć pewną oględność sformułowań, dystansowanie się od poglądu, że antysemityzm, zwłaszcza rasistowski, mógłby być w jakiejś mierze skutkiem (immanentnego) antyjudaizmu kultury chrześcijańskiej; chrześcijan umieszcza się raczej po stronie ofiar, razem z Żydami. W jednym ze swych przemówień Jan Paweł II wprost mówi:

„Byłoby zapewne rzeczą niesłuszną i niezgodną z prawdą, gdyby się chciało te niewypowiedziane zbrodnie kłaść na karb chrześcijaństwa. Ujawnia się w nich raczej straszliwe oblicze świata bez Boga, a nawet przeciwnego Bogu - świata, którego niszczące zamiary kierowały się zgodnie z deklaracjami przeciw narodowi żydowskiemu, ale także przeciwko wierze tych, którzy w osobie Żyda Jezusa Chrystusa czczą Zbawiciela świata" (Chrostowski \& Rubinkiewicz, 1990, s. 216).

Symptomatyczne jest także, iż zarówno w przeprosinach Jana Pawła II, jak i w innych oficjalnych dokumentach, nie mówi się o winach Kościoła, ale o winach córek i synów Kościoła (także: ludu, chrześcijan, tych, którzy przysporzyli cierpień). W ten sposób obroniona zostaje idea świętości Kościoła (por. tytuł książki ks. Jana Kracika, Święty Kościół grzesznych ludzi, Kraków 1998). Scedowanie odpowiedzialności na córki i synów w oczywisty sposób umniejsza skalę i rangę odpowiedzialności Kościoła, nadaje taki charakter złu, który polega na sprzeniewierzeniu się grzesznych ludzi przesłaniu chrześcijaństwa, ale w żadnym razie nie wynika z treści tkwiących w samym jego centrum.

\section{Wspótczesny polski negatywny dyskurs o Żydach}

Przemiany zainicjowane przez Sobór Watykański II, które (jakkolwiek niedogłębne) znalazły wyraźne odzwierciedlenie w oficjalnym dyskursie Kościoła, nie ogarnęły jednak wszystkich nadawców katolickich. Ostatnia część niniejszego artykułu przedstawia ten nurt w polskiej przestrzeni dyskursywnej, który świadczy o nieprzyswojeniu soborowej odnowy.

Mimo iż Żydów praktycznie w Polsce nie ma, narracja o nich może się toczyć, ponieważ wszystkie mity na ich temat przekazywane z pokolenia na pokolenie od wieków wciąż pozostają żywe. Antyżydowskie stereotypy tak głęboko zakorzeniły się w podświadomości społeczeństw europejskich, w tym społeczeństwa polskiego, iż - twierdzi Joanna Tokarska-Bakir - praca nad nimi pod wieloma względami przypomina psychoanalizę (Tokarska-Bakir, 2008, s. 47).

SLH 3/4 2014/2015 | str. 290 
Jak pisze historyczka, Alina Cała, w czasach PRL negatywny wizerunek Żyda transmitowany był głównie przez przekaz międzypokoleniowy, w mniejszym zaś stopniu za pośrednictwem wygłaszanych z ambony kazań czy nauczania podczas katechezy (Cała, 2012, s. 540). Jednak milczenie Kościoła przyczyniło się do podtrzymania żywotności tego przekazu, ponieważ nad aspektem pozytywnym owego milczenia (odstąpienie od kontynuacji antyżydowskich wątków w pewnej mierze wymuszone przez państwową cenzurę) przeważył aspekt negatywny. Bardziej bowiem było to milczenie obojętności, odrzucenie szansy na uświadomienie Polakom istoty Holokaustu, który, jak widać, dla wielu katolickich nadawców nie stał się wydarzeniem dość wstrząsającym i traumatycznym, by skłonić do refleksji zmieniającej krzywdzące nawyki myślowe, postawy i zachowania. Za najważniejsze zadanie Kościoła w Polsce odsuwające „na bok” (lub na „lepsze czasy”) wszystko inne uznano przeprowadzenie narodu polskiego przez Morze Czerwone komunizmu, przy czym pojęcie Narodu 8 polskiego - zarówno w nauczaniu prymasa Stefana Wyszyńskiego, jak i polskiego episkopatu - konsekwentnie ograniczano do Polaków-katolików, wspólnoty jednorodnej etnicznie (rodzina rodzin), ale i wyznaniowo (Polonia semper fidelis - 'Polska zawsze wierna papieżowi'). Istotny w tym nauczaniu wątek martyrologiczny również dotyczył tak właśnie zdefiniowanego $\mathrm{Na}$ rodu, a więc tylko cierpień Polaków, szczególnie „wywyższonych” w owym cierpieniu (por. mesjański mit Polski jako Chrystusa narodów). Skoncentrowanie się na własnym bólu niejako z zasady nie pozostawia miejsca na empatię dla innych (por. Janion, 2006, s. 19). Zarazem też silnie gloryfikowano i idealizowano Polaków jako naród o wyjątkowo szlachetnym charakterze, ukształtowanym przez chrześcijaństwo, krzywdzony, ale niezdolny do krzywdzenia innych (por. Skowronek, 2006). W takim dyskursie więc nie był możliwy żaden moralny rozrachunek, o jakim pisze Daniel Goldhagen (Goldhagen, 2005), żaden wątek, który mógłby zagrozić tak kreowanemu wizerunkowi Narodu. Co prawda, w 1968 roku (w związku z tzw. wydarzeniami marcowymi) prymas Wyszyński oraz polscy biskupi potępili antysemityzm, ale niczego to nie zmieniało w obrazie polskości.

Antysemityzm, praktycznie niepoddany refleksji ${ }^{9}$, przetrwał więc wśród wielu Polaków, w tym także duchownych. Po roku 1989, negatywny dyskurs o Żydach rozwijat się przede wszystkich w kręgu polskiego katolicyzmu określanego jako „radiomaryjny” (zob. Bobrowska, 2007). Tworzą go głównie nadawcy (i wierni odbiorcy) Radia Maryja oraz zespołu mediów, które są z nim (ideowo oraz personalnie) związane, jak m.in. ogólnopolska gazeta „Nasz Dziennik”, mająca wielu czytelników i szeroki zakres oddziaływania społecznego. Według szacunków liczba polskich katolików pozostających pod wpływem konglomeratu medialnego Radia Maryja może wynosić nawet 6 milionów (zob. Bobrowska, 2007, s. 8).

8 Zarówno w listach pasterskich prymasa Wyszyńskiego, jak i Episkopatu Polski wyraz Naród zawsze pisany jest wielką literą, co jest również jednym ze środków gloryfikacji i idealizacji Polaków.

9 Pewnym wyjątkiem, choć o ograniczonym zasięgu, była działalność środowiska intelektualistów skupionych wokół „Tygodnika Powszechnego”, „Znaku” i „Więzi”, które podjęło próbę dyskusji na temat pamięci o Żydach i ich zagładzie (zob. Cała, 2012, s. 541)

SLH 3/4 2014/2015 | str. 291 
Dyskurs ten pod wieloma względami przypomina czasy przedwojenne. Znów zastosowanie znalazły środki zaznaczania dystansu między nami, Polakami a Żydami jako grupą inną niż my. Dziś jednak ich obecność kreuje się jako ukrytą, zakonspirowaną i przyjmuje się za cel demaskowanie tejże obecności, na przykład w formie list Żydów ukrywających swoje pochodzenie (zob. Tokarska-Bakir, 2008, s. 616), wzmiankując fakt bycia Żydem przy okazji prezentacji danej osoby (np. Michael Weintraub, pochodzenia żydowskiego) lub w postaci kontaminacji typu Józef Żydziński (Życiński), politycy europejsy (europejscy) itp. Obraz obecności Żydów w polskim życiu publicznym wywoływać mają deskrypcje takie, jak żydowskie: lobby, kręgi, środowisko, organizacje, gminy; żydowska strona; kapitat żydowski itp., które - de facto nieokreślone - jedynie pozornie identyfikują desygnaty.

Demaskowaniu podlega jednak przede wszystkim działalność Żydów określona przez tradycyjne mity, które zyskały nowe, współczesne aktualizacje. Szkodzenie Polsce tym razem przybrało formę rujnowania opinii Polaków w oczach świata, głównie przez kłamliwe oskarżanie ich o udział w Holokauście. W budowaniu tego wątku biorą udział nazwy czynności polegających na naruszaniu normy prawdy w celu moralnego i psychicznego krzywdzenia polskiego społeczeństwa: szkalowanie Polski; odebranie dobrego imienia Polsce; spotwarzać, oskarżać, pograżać, oczerniać, lżyć, znieważanie Narodu; zohydzić Polskę opinii światowej; Polska będzie upokarzana na arenie międzynarodowej; kampania kłamstw i oszczerstw; kłamliwa, antypolska propaganda; antypolskie brednie; pomówienia. Szczególnie wyróżnionym „bohaterem” wątku szkodzenia Polakom na tym polu stał się historyk Jan Tomasz Gross, autor książki o wymordowaniu przez Polaków żydowskich współmieszkańców w miasteczku Jedwabne. Głoszone przez niego tezy dyskredytowano za pomocą ataków na osobę autora (tże-profesor, obsceniczny kłamca, polakożerczy hochsztapler zza oceanu, wampir historiografii ${ }^{10}$ itp.) lub jego książki (publicystyczny paszkwil, polakożerczy gniot, polityczna pornografia, pokraczne dzieło, „zjawisko kulturowe” godne porównania tylko z Doda-Elektroda itp.).

Celem oszczerczej działalności Żydów jest w tej narracji wyłudzenie korzyści materialnych (wyciągnąć materialne korzyści; zaspokoić żydowskie żądania materialne; wyciagnać od Polski 60 miliardów dolarów; wymuszanie / wyłudzanie pieniędzy od Polski; wydarcie Polsce dobrego imienia, kolejnych dolarów). Mit chciwego Żyda powrócił bowiem jako oskarżenie, że Żydzi po wojnie wykorzystują Zagładę dla pomnożenia swego bogactwa. Symptomatyczna jest frekwencja wyrazów z leksykalnego pola handlu, jak pieniądze, interes, biznes, profity finansowe, zyski, zarabiać oraz gescheft (lub geszeft), których obecność ma stanowić akt werbalnego odsłonięcia tego, co ma pozostać ukryte - wydobycia na światło dzienne niskiego motywu działań Żydów. Słowo pieniądze bywa wielokrotnie powtarzane, żeby zbitka skojarzeniowa Żydzi - pieniądze dobrze się utrwaliła w świadomości odbiorców, na przykład:

„Kiedy w Hollywood mówi się, że nie chodzi o pieniądze, to znaczy, że właśnie chodzi o pieniądze. Kiedy żydowskie organizacje atakują Polaków za ich domniemany współudział w ho-

10 O figurze wampira, krwiopijcy będącej upostaciowaniem wyobrażenia tego, który szkodzi (nam - grupie dominującej) zob. Tokarska-Bakir, 2012, ss. 113-141. 
lokauście, chodzi także o pieniądze, a nie o moralne zadośćuczynienie i pamięć o zamordowanych w czasie wojny współwyznawcach" (Nasz Dziennik, 21.05.2001; cyt. za: Kowalski \& Tulli, 2003, s. 89).

Mówienie o żydowskich roszczeniach majątkowych apeluje też do lęku przed utratą własności (domu, warsztatu pracy). Straszeniu przed powrotem właścicieli żydowskich służą obrazy niesprawiedliwości przedwojennego kapitalizmu oraz słownictwo katastroficzne typu: zguba, ruina (por. Lista znanych Żydów doprowadzających Polskę do ruiny; cyt. za: Tokarska-Bakir, 2008, s. 621).

Szczególnie dezawuujący charakter mają takie wyrażenia, jak: przedsiębiorstwo holokaust, holokaust biznes, biznes holocaustu, holocaust-gescheft, przemyst holokaustu, szoahbiznes, holocaust-biznesmeni, które najzupełniej otwarcie przypisują Żydom zorganizowane, planowe działanie, obliczone na czerpanie dochodów z tytułu doznanych prześladowań. Nawiasem mówiąc, termin przedsiębiorstwo holokaust (holocaust industry) został podchwycony i przeniesiony na grunt polski z książki amerykańskiego historyka Normana G. Finkelsteina (wyd. polskie: Finkelstein, 2001).

Motyw szkodzenia rozwijają wątki historyczne: oskarżenia Żydów o kolaborację z Niemcami podczas okupacji (w tym o pomoc świadczoną nazistom nawet w zagładzie własnego narodu) oraz o gorliwy współudział w zbrodniach stalinowskich. Eksponuje się cynizm, okrucieństwo i podłość Żydów, wiążąc z nimi silnie piętnujące kwalifikacje (zbrodniarz, oprawca, mordować; stalinowskie świnienia, podłe donosicielstwo, haniebny epizod w życiu Hollanda, działalność rabunkowa band żydowskich itp.).

Dla współczesnego dyskursu antyżydowskiego charakterystyczny jest też wątek, który Sergiusz Kowalski i Magdalena Tulli nazwali „wyścigiem ofiar”, czyli swoiste licytowanie się o to, który naród - żydowski czy polski - poniósł dotkliwsze straty (Kowalski \& Tulli, 2003). Propaguje się tezę, że skala własnych ofiar jest przez Żydów wyolbrzymiana, a ofiar polskich - pomniejszana. Zadaniem wielu wypowiedzi jest więc „korygowanie” tego historycznego „fałszu”, na przykład przez otwarte stwierdzenia, że ofiar polskich było więcej, lub przez przywoływanie przykładów współczesnego ludobójstwa, wobec których tragedia Żydów jawi się jako bynajmniej nie największa i nie wyjątkowa w dziejach ludzkości. Istotnym składnikiem tego wątku jest podkreślanie roli Polaków, którzy z narażeniem życia ratowali Żydów podczas niemieckiej okupacji, dzięki czemu skala Zagłady nie była tak wielka, jak twierdzi się w żydowskiej kampanii kłamstw i oszczerstw. Antidotum na tę kampanię stanowić mają głównie relacje wspomnieniowe i biografie osób (ze szczególnym uwzględnieniem duchownych), które pomagały Żydom przetrwać wojnę. Ale sięga się też do różnych technik mówienia nie wprost, tak jak w poniższym fragmencie, z którego odbiorcy sami mają wyciągnąć wniosek o niedorzeczności żydowskich opowieści:

„Jeśli podczas wojny Polacy nie uratowali nieprzeliczonej rzeszy żydowskich chłopców, skąd w dzisiejszym Nowym Jorku czy Tel Awiwie wzięła się nieprzeliczona rzesza żydowskich dziadków świetnie mówiących po polsku" (Nasz Dziennik, 23.10.2001; cyt. za: Kowalski \& Tulli, 2003, s. 134). 
Znamienne dla tego dyskursu jest negowanie istnienia antysemityzmu w Polsce, usuwanie tego pojęcia niejako poza obręb polszczyzny jako niepotrzebnego, pozbawionego desygnatu. Wyraz antysemityzm umieszcza się w związku z tym w cudzysłowie, opatruje operatorami modalności epistemicznej rzekomy / domniemany lub kwalifikuje za pomocą słownictwa oznaczającego niezgodność z prawdą, jak mit, stereotyp, schematy, uprzedzenia, uogólnienia, fobie, zafałszować, wmawiać itp.

Oskarża się wreszcie wyznawców judaizmu o niezdolność do dialogu, cyniczne wykorzystywanie dobrej woli chrześcijan do własnych doraźnych celów politycznych. Z surowym osądem spotykają się katolicy zaangażowani w dialog chrześcijańsko-żydowski, których określa się jako naiwnych, spolegliwych zakładników Żydów, chcących im się przypodobać, stosujących umizgi wobec nich, poddających się żydowskiemu dyktatowi i hipokryzji, jako ofiary dialogomanii i dialogolatrii.

Wbrew postulatom ostatniego soboru oraz temu, czego nauczał Jan Paweł II, widać więc wszystkie wyraziste rysy obcego i wroga, złego i groźnego, którego trzeba nieustannie demaskować i toczyć z nim walkę (o prawdę, pamięć, godność Polaków, ich zagrożone mienie). Zarówno pod względem treści, jak i środków językowo-retorycznych (pejoratywizmy, dyskredytacja itp.) ten nurt dyskursu bliższy jest przedwojennemu modelowi mówienia o Żydach niż temu, który realizował papież, pragnąc zarazem, by model ów stał się wzorem dla wszystkich, a dla jego rodaków w szczególności.

\section{Źródła:}

„Nasz Dziennik”.

„Pro Christo. Wiara i czyn. Organ młodych katolików”.

„Przewodnik Katolicki”, Poznań.

Bukowski, K. (2004). Homilie. Niedziele i święta roku A. Kraków: „eSPe”.

Chabiński, S. (2004). Z Bogiem przez życie. Modlitewnik dla młodzieży. Ząbki: „Apostolicum”.

Chrostowski, W., \& Rubinkiewicz, R. (Red.). (1990). Żydzi i judaizm w dokumentach Kościoła i nauczaniu Jana Pawła II (1965-1989). Warszawa: Akademia Teologii Katolickiej.

Skarbiec modlitw i pieśni. Książka diecezjalna do nabożeństwa dla katolików każdego stanu i wieku... (1947). Katowice.

„Wielki Tydzień”. Przewodnik obrzędów i modlitw wielkotygodniowych. (1937). J. L. (Red.). Potulice.

\section{Bibliografia:}

Bobrowska, E. (2007). Obrazowanie społeczeństwa w mediach. Analiza radiomaryjnego dyskursu. Kraków: Wydawnictwo Uniwersytetu Jagiellońskiego.

Bralczyk, J. (2007). O języku propagandy i polityki. Warszawa: Wydawnictwo Trio.

Cała, A. (2012). Żyd - wróg odwieczny? Antysemityzm w Polsce i jego źródła. Warszawa: Wydawnictwo Nisza.

Czajkowski, M. (2000). Ekumeniczny akt pokuty. Przegląd Pastoralno-Homiletyczny, (4).

Finkelstein, N. G. (2001). Przedsiębiorstwo holokaust. (M. Szymański, Tłum.). Warszawa: „Volumen”.

SLH 3/4 2014/2015 | str. 294 
Fry, H. P. (Red.). (2003). Dialog chrześcijańsko-żydowski. Antologia tekstów. (E. Dargiewicz \& A. Kuśmirek, Tłum.). Warszawa: Wydawnictwo Uniwersytetu Kardynała Stefana Wyszyńskiego.

Garpiel, R. (2003). Perswazja w przekazach kaznodziejskich na przykładzie homilii Jana Pawła II wygłaszanych podczas pielgrzymki do Polski w 1979 roku. Kraków: „Nomos”.

Goldhagen, D. J. (2005). Niedokończony rozrachunek. Rola Kościoła katolickiego w Holocauście i niedopełniony obowiązek zadośćuczynienia. (H. Jankowska, Tłum.). Warszawa: „Sic!”.

Janion, M. (2006, maj 27-28). Moje herezje antynarodowe. Gazeta Wyborcza.

Klemperer, V. (1989). LTI. Notatnik filologa. (J. Zychowicz, Tłum.). Warszawa: Młodzieżowa Agencja Wydawnicza.

Korolko, M. (2001). „Mąż Boleści” w staropolskich pieśniach pasyjnych. W P. Nowaczyński (Red.), Chrystus w literaturze polskiej. Lublin: Katolicki Uniwersytet Lubelski.

Kowalski, S., \& Tulli, M. (2003). Zamiast procesu. Raport o mowie nienawiści. Warszawa: W.A.B.

Krzeszowski, T. P. (1998). Aksjologiczne aspekty metafor. W W. Kubiński, R. Kalisz, \& E. Modrzejewska (Red.), Językoznawstwo kognitywne. Wybór tekstów. Gdańsk: Wydawnictwo Uniwersytetu Gdańskiego.

Makuchowska, M. (2011). Od wrogów do braci. Posoborowe zmiany w dyskursie Kościoła katolickiego. Opole: Wydawnictwo Uniwersytetu Opolskiego.

Michałowska, T. (2006). Średniowiecze. Warszawa: Wydawnictwo Naukowe PWN.

Modras, R. (2004). Kościót katolicki i antysemityzm w Polsce w latach 1933-1939. (W. Turopolski, Tłum.). Kraków: Homini.

Musiat, S. (2001). Sabotaż teologiczny. Wprost, (15). Pobrano z http://www.wprost.pl/ar/9764/Sabotaz-teologiczny/?pg=1

Muszyński, H. (1990). Wstęp. W W. Chrostowski \& R. Rubinkiewicz (Red.), Żydzi i judaizm w dokumentach Kościoła i nauczaniu Jana Pawła II (1965-1989). Warszawa: Akademia Teologii Katolickiej.

Nostra aetate. (2009). Deklaracja Soboru Watykańskiego II o stosunku Kościoła do religii niechrześcijańskich „Nostra aetate". Pobrano z http://religie.wiara.pl/doc/471908.Nostra-aetate-Deklaracja-Soboru-Watykanskiego-II-o-stosunku

Pałka, D. (2006). Kościót katolicki wobec Żydów w Polsce międzywojennej. Kraków: „Nomos”.

Petuchowski, J. J., \& Thoma, C. (1995). Leksykon dialogu chrześcijańsko-żydowskiego. (J. Kruczyńska, Tłum.). Warszawa: Akademia Teologii Katolickiej.

Puzynina, J. (1992). Język wartości. Warszawa: Wydawnictwo Naukowe PWN.

Sieg, U. (1989, grudzień 22). Die Verjudung des deutschen Geistes. Die Zeit, s. 50.

Skowronek, K. (2006). Między sacrum a profanum. Studium językoznawcze listów pasterskich Konferencji Episkopatu Polski (1945-2005). Kraków: LEXIS.

SJPSz - Szymczak, M. (Red.). (1981). Słownik języka polskiego. Warszawa: Wydawnictwo Naukowe PWN.

Tokarska-Bakir, J. (2008). Legendy o krwi. Antropologia przesądu. Warszawa: W.A.B.

Tokarska-Bakir, J. (2012). Okrzyki pogromowe. Szkice z antropologii historycznej Polski lat 1939-1946. Wołowiec: Czarne. Wenzel, K. (2007). Mała historia Soboru Watykańskiego II. (J. Zychowicz, Tłum.). Kraków: Wydawnictwo WAM.

Wiltgen, R. M. (2001). Ren wpada do Tybru. Historia Soboru Watykańskiego II. (A. Słowik, Tłum.). Poznań: Klub Książki Katolickiej.

Wojtyska, H. D., \& Kopeć, J. J. (Red.). (1981). Męka Chrystusa wczoraj i dziś. Lublin: Katolicki Uniwersytet Lubelski.

Woźniak, E. (2007). Ofiary i krzywdziciele. Studium postaci w przedtrydenckim piśmiennictwie pasyjnym. Analiza językoznawcza. Łódź: Wydawnictwo Uniwersytetu Łódzkiego.

Zuberbier, A. (1990). Wprowadzenie. W W. Chrostowski \& R. Rubinkiewicz (Red.), Żydzi i judaizm w dokumentach Kościota i nauczaniu Jana Pawła Il (1965-1989). Warszawa: Akademia Teologii Katolickiej. 


\section{Jews in the discourse of the Catholic Church}

Abstract: The article describes the most important changes which appeared after the Second Vatican Council in the discourse of the Catholic Church in reference to its attitude to confessors of Judaism. The change is the difference between the state of texts in two different moments, which is why the first part of the article is dedicated to the characteristics of pre-Council (and mostly pre-war) discourse about Jews, and the second part to main directions of the changes caused by the realization of the Council postulates. The third part shows indications of the continuation of old, deep-rooted schemes. The analysis partly concerns texts of the Church worldwide, and partly texts of the Church in Poland.

Polish pre-Council discourse on Jews was characterized by exceptional negativism. Catholic liturgy shows them as those who tortured and killed Jesus (the myth of deicides). In the sermons, pastoral letters and the Catholic press, Jews were presented as enemies of not only Christianity but also of Poles, because the Church in Poland engaged itself in creation of the nationally and religiously homogenous country under the slogan "Poland for Poles." All the traditional myths were reproduced (Jews as wreckers, conspirators, debauchers, etc.). Many linguistic means were applied to degrade Jews, for example deminutiva, animalization (speaking about Jews as about animals), so-called cacophemism, words with pejorative meaning of moral and physical disgust.

After Vaticanum // contents, which reproduced the picture of Jews as deicides, were removed from the Catholic liturgy. The positive pictures of Jews and Judaism were consequently created in the tuition of Pope John Paul II and Benedict XVI. Linguistic means emphasize the community of Christians and Jews (bond, closeness, brothers, brotherhood, togetherness, etc.). Each pope obliges Catholics to respect Jews and memory of Holocaust; popes directly prohibit any signs of anti-Semitism.

After 1989 in Poland anti-Jewish inclinations returned, especially in the circle of the so callled Catholicism of the Maryja Radio. Again Jews are accused of causing damage to Poles, and the language of those statements is very much like in the discourse before the Council.

Keywords: discourse of Catholic Church; Vatican Council II; Jews; linguistic means; discrediting; stereotypes

This is an Open Access article distributed under the terms of the Creative Commons Attribution 3.0 PL License, which permits redistribution, commercial and non-commercial, provided that the article is properly cited. www.creativecommons.org/licenses/by/3.0/pl

(c) The Author(s) $2014 / 2015$

Publisher: Institute of Slavic Studies PAS [Wydawca: Instytut Slawistyki PAN]

DOI: $10.11649 /$ slh.2015.015

Author: Marzena Makuchowska, Uniwersytet Opolski, Opole

Correspondence: marzena.makuchowska@uni.opole.pl

The work has been prepared on author's own expense.

Competing interests: No competing interests has been declared. 